\title{
Passive Fiber Optic Evanescent Wave Sensor for the Measurement of Refractive Index at Various Temperatures using a Tunable Light Source
}

\author{
S. Srinivasulu, S. Venkateswara Rao
}

\begin{abstract}
The study of refractive index of liquids over a range of $100 \mathrm{C}$ to $600 \mathrm{C}$ shows very interesting results to design and develop a highly sensitive passive fiber optic sensor based on a $U$-shaped glass probe. The depth of penetration of light that escaping from the core of the fiber into the cladding plays a crucial role in the development of a highly sensitive fiber optic evanescent wave sensor. The depth of penetration of an optical fiber striped off its cladding is directly related to the wavelength of the light, the index of refraction of the surrounding medium, the angle of incidence of light, the bending radius and thickness of the $U$-shaped probe. In the design of the sensor a $U$-shaped glass probe is used to replace the core of the fiber in the region of sensing, the diameter of which is same as that of the cores of a pair of insensitive fibers which in-turn connected to a tunable light source and an optical detector. The sensor is highly reliable, robust and easy to configure using multimode PCS fibers and the source operating at the wavelengths of 630nm, 660nm, 820nm and 850nm.
\end{abstract}

Keywords:Depth of penetration, Fiber optic evanescent wave sensor, insensitive fibers, Optical detector, Tunable light source, $U$-shaped glass probe.

\section{INTRODUCTION}

The evanescent wave penetrates into the analyte ranges from ten to several hundred nanometers during course of its interaction of an analyte with the escaping field of light that traverses through an optical fiber. Because of its short range depth of penetration of the evanescent wave, the measurements are not affected by bulk solution [1]. The fiber optic evanescent wave sensors consisting of a plastic clad silica core optical fibers are now a days have been used in a wide range of fields such as chemical, biochemical, food technology, fragrant, beverages, life sciences and environmental research, etc [2-3]. The sensitivity offered by the evanescent wave sensors are very high comparing to the other kinds of sensors based on various designs [4]. For the enhancement of the sensitivity of the fiber optic evanescent wave sensor various geometries have been considered to measure innumerable environmental parameters [5]. Majority of the schemes of the fiber optic evanescent wave sensors have concentrated on the optimization of the shape of the sensing element and the end of the probe in the region of sensing. Many researchers have used the techniques of

Revised Manuscript Received on July 22, 2019.

S. Srinivasulu, Department of Physics, College of Engineering Hyderabad, J N T University Hyderabad - 500085, Telangana State, India

Dr. S. Venkateswara Rao, Department of Physics, College of Engineering Hyderabad, J N T University Hyderabad - 500085, Telangana State, India surface plasma resonance (SPR) to enhance further the specificity and sensitivity of the evanescent wave sensors [6]. The intensity of the evanescent field on the unclad fiber surface is very important in developing the enhanced sensitive evanescent field sensor [7]. The sensitivity of the sensor depends upon increase in the amount of light escaping into the analyte and decreases in the number of meridional rays propagate within the fiber. The loss of evanescent wave is determined by number of total reflections and their depth of penetration. The transmission spectrum of fiber is sensitive to various measurands such as temperature, strain [8], external refractive index [9-10] and bend radius [11-14]. Corresponding to each measurand the attenuation band shows a different sensitivity offering for the construction of multi-parameter sensing systems [15]. It is possible to extract a wide range of quantitative information, moment of a single cell and composition using the measurement of evanescent wave. For the study of rate of chemical reaction, thin films of organic metals, curing of complex material, liquid solid interfaces, gas and liquid detection and biological applications, etc, using probe or sensing element in the construction of an evanescent wave sensor have been reported [16-18]. The evanescent wave penetrates into the surrounding and accordingly the power in the core decreases exponentially when the surrounding medium refractive index is close to less than $5 \%$ of the core and fiber cladding is 5units of wavelength in thickness [19].

\section{EXPERIMENTAL DETAILS}

The experimental Procedure was initiated by properly selecting the various components that forms part of the experimental arrangement. For the effective measurement of the refractive index of liquids a tunable light source was selected along with other necessary components listed as under.

1. A tunable light source (LASER diode) operating at the wavelengths of $630 \mathrm{~nm}, 660 \mathrm{~nm}, 820 \mathrm{~nm}$ and $850 \mathrm{~nm}$

2. A benchmark light detector operating at the wavelengths of $630 \mathrm{~nm}, 660 \mathrm{~nm}, 820 \mathrm{~nm}$ and $850 \mathrm{~nm}$.

3. A pair of plastic clad silica (PCS) fibers of $200 / 230 \mu \mathrm{m}$ core and cladding diameters respectively.

4. A borosilicate glass rod bent in the form of a U-shape, the thickness of which is equal to diameter of the core of a pair of multimode PCS fibers used in the experiment. 
5. A two burette system to measure the volumes of liquid mixtures in required ratios.

6. An automatic digital refractometer of modal number RX-7000i (Atago make).
7. An electric kettle heater to heat the chemical mixture to above the room temperature.

8. An ice bath arrangement to reduce the temperature of chemical mixture below room temperature down to $10^{\circ} \mathrm{C}$.

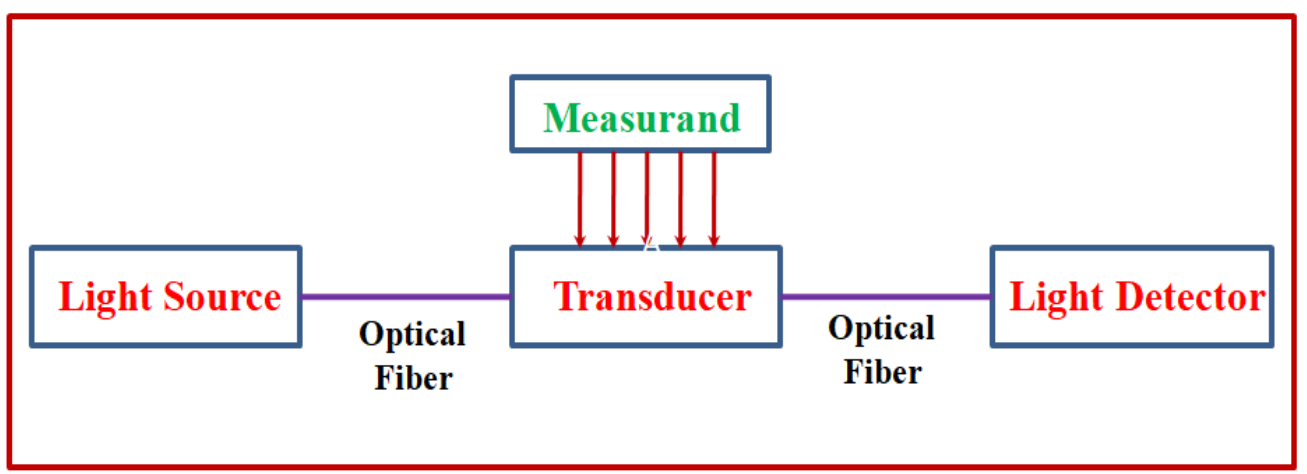

Figure.1: Block diagram of fiber optic sensor system.

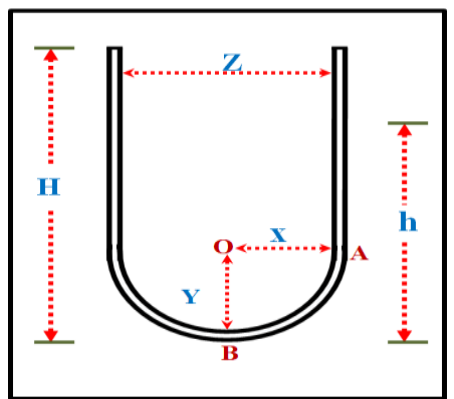

Thickness of rod:

$0.5 \mathrm{~mm}$

Total height of the glass $\operatorname{rod}(\mathrm{H})$ :

$40 \mathrm{~mm}$

Depth of the glass rod immersed in liquid(h): $30 \mathrm{~mm}$

Width between two prongs(Z):

$5 \mathrm{~mm}$

Radius of the Curvature $(\mathrm{X})$ :

$2.5 \mathrm{~mm}$

Depth of the Curvature(Y):

$2.5 \mathrm{~mm}$

Figure.2: Geometrical parameters of $U$-shaped borosilicate glass probe.

Chemical parameter of Toluene $\left(\mathrm{C}_{7} \mathrm{H}_{8}\right)$ :<smiles>Cc1ccccc1</smiles>

CAS Number:

108-88-3

Molar Mass (g/mole):

92.141

Refractive index (n):

1.4967 at $20^{\circ} \mathrm{C}$

$\operatorname{Density}(\rho)\left(\mathrm{kg} / \mathrm{m}^{3}\right)$ :

$0.8697 \times 10^{3}$ at $20^{\circ} \mathrm{C}$

Color:

Colorless

Boiling Point $\left({ }^{\circ} \mathrm{C}\right)$ :

$110.6^{\circ} \mathrm{C}$

\section{Chemical parameter of Acetone $\left(\mathrm{C}_{3} \mathrm{H}_{6} \mathrm{O}\right)$ :}

Structure:<smiles>CC(C)=O</smiles>

CAS Number:

67-64-1

Molar Mass (g/mole):

58.080

Refractive index (n):

1.3588 at $20^{\circ} \mathrm{C}$

$\operatorname{Density}(\rho)\left(\mathrm{kg} / \mathrm{m}^{3}\right)$ :

$0.7845 \times 10^{3}$ at $20^{\circ} \mathrm{C}$

Color:

Colorless

Boiling Point $\left({ }^{\circ} \mathrm{C}\right)$ : 
The assembly of the experimental arrangement consist of a uniform U-shaped glass rod connected between a tunable light source operating at the wavelengths of $630 \mathrm{~nm}, 660 \mathrm{~nm}$, $820 \mathrm{~nm}$ and $850 \mathrm{~nm}$ and a benchmark light detector by using a pair of PCS fibers. A two burette system fixed at certain height using stands, the mixture of Toluene and Acetone is taken in different proportions making the total volume equal to $20 \mathrm{ml}$ and each is preserved in a separate glass bottle closed with air tight lids. Launching light into the sensor by tuning the source to the operating wavelength of $630 \mathrm{~nm}$, the U-shaped glass rod is immersed in first mixture of Toluene and Acetone with the ratio of $20 \mathrm{ml}+0 \mathrm{ml}$ and the power output is noted from the detector at room temperature.
The procedure is repeated by rising the temperature of the mixture to $60^{\circ} \mathrm{C}$ in steps of $5^{\circ} \mathrm{C}$ each using electric kettle heater and the observations are recorded. Similar method is used when the temperature of the mixture decreased from room temperature to $10^{\circ} \mathrm{C}$ in steps of $5^{\circ} \mathrm{C}$ each using a cooling setup consisting of an ice bath and a thermometer.

The above steps of experimental method was followed using the other mixtures of the combination of Toluene and Acetone and the results obtained are recorded for all the different temperatures i.e. at room temperature, above room temperature up to $60^{\circ} \mathrm{C}$ and below room temperature up to $10^{\circ} \mathrm{C}$ and all the observations are noted [table-1].

Table.1: Mole fraction and concentration of Acetone in Toluene + Acetone chemical mixture and Output power at various temperatures for the operating wavelength of the source $630 \mathrm{~nm}$.

\begin{tabular}{|c|c|c|c|c|c|c|c|c|c|c|c|c|c|}
\hline \multirow{2}{*}{$\begin{array}{c}\text { S. } \\
\text { No. }\end{array}$} & \multirow{2}{*}{$\begin{array}{c}\text { Mole } \\
\text { fraction } \\
\text { of } \\
\text { Acetone }\end{array}$} & \multirow{2}{*}{$\begin{array}{l}\text { Concentration } \\
\text { of Acetone }\end{array}$} & \multicolumn{11}{|c|}{ Output Power(dBm) at various temperatures } \\
\hline & & & $10^{\circ} \mathrm{C}$ & $15^{\circ} \mathrm{C}$ & $20^{\circ} \mathrm{C}$ & $25^{\circ} \mathrm{C}$ & $30^{\circ} \mathrm{C}$ & $35^{\circ} \mathrm{C}$ & $40^{\circ} \mathrm{C}$ & $45^{\circ} \mathrm{C}$ & $50^{\circ} \mathrm{C}$ & $55^{\circ} \mathrm{C}$ & $60^{\circ} \mathrm{C}$ \\
\hline 1 & 0.0000 & $0 \%$ & -44.90 & -44.53 & -44.17 & -43.73 & -43.33 & -42.97 & -42.57 & -42.27 & -41.77 & -41.47 & -41.10 \\
\hline 2 & 0.0718 & & 43.00 & -42.60 & -42.33 & נד. & & -41.53 & -41.30 & -41.00 & -40.73 & -40.33 & -40.00 \\
\hline 3 & 0.1483 & & -41.57 & -41.33 & -41.07 & -40.73 & -40.43 & -40.10 & -39.83 & -39.50 & -39.20 & -38.90 & -38.57 \\
\hline 4 & 0.2299 & & 0.53 & -40.20 & -39.93 & -59.31 & -39.30 & -39.00 & -38.73 & -38.43 & -38.00 & -37.83 & -37.53 \\
\hline 5 & 0.3171 & & 39.17 & -38.90 & -38.57 & -38.30 & -37.97 & -37.77 & -37.47 & -37.13 & -36.83 & -36.50 & -36.27 \\
\hline 6 & 0.4106 & $50 \%$ & 37.97 & -37.77 & -37.47 & -37.13 & -36.83 & -36.50 & -36.27 & -35.90 & -35.60 & -35.30 & -35.07 \\
\hline 7 & 0.5110 & $60 \%$ & -36.70 & -36.40 & -36.13 & -35.83 & -35.53 & -35.23 & -35.00 & -34.63 & -34.33 & -34.00 & -33.70 \\
\hline 8 & 0.6191 & $70 \%$ & -35.07 & -34.70 & -34.40 & -34.10 & -33.80 & -33.47 & -33.20 & -32.90 & -32.60 & -32.33 & -32.00 \\
\hline 9 & 0.7359 & $80 \%$ & -33.53 & -33.20 & -32.90 & -32.60 & -32.33 & -32.00 & -31.73 & -31.40 & -31.10 & -30.80 & -30.50 \\
\hline 10 & 0.8624 & $90 \%$ & -31.83 & -31.53 & -31.20 & -30.93 & -30.57 & -30.27 & -30.07 & -29.80 & -29.60 & -29.40 & -29.13 \\
\hline 11 & 1.0000 & $100 \%$ & -30.50 & -30.27 & -29.97 & -29.70 & -29.57 & -29.30 & -29.03 & -28.77 & -28.43 & -28.17 & -27.80 \\
\hline
\end{tabular}

Next, the source is tuned to the operating wavelength of $660 \mathrm{~nm}$ and using all the mixtures one by one at the temperatures ranging from $10^{\circ} \mathrm{C}$ to $60^{\circ} \mathrm{C}$ using ice bath and electric kettle heater, the output powers corresponding to each mixture is noted from the detector and were recorded [table-2].

Table.2: Mole fraction and concentration of Acetone in Toluene + Acetone chemical mixture and Output power at various temperatures for the operating wavelength of the source $660 \mathrm{~nm}$.

\begin{tabular}{|c|c|c|c|c|c|c|c|c|c|c|c|c|c|}
\hline \multirow{2}{*}{$\begin{array}{c}\text { S. } \\
\text { No. }\end{array}$} & \multirow{2}{*}{$\begin{array}{c}\text { Mole } \\
\text { fraction } \\
\text { of } \\
\text { Acetone }\end{array}$} & \multirow{2}{*}{$\begin{array}{c}\text { Concentration } \\
\text { of Acetone }\end{array}$} & \multicolumn{11}{|c|}{ Output Power(dBm) at various temperatures } \\
\hline & & & $10^{\circ} \mathrm{C}$ & $15^{\circ} \mathrm{C}$ & $20^{\circ} \mathrm{C}$ & $25^{\circ} \mathrm{C}$ & $3^{\circ} \mathrm{C}$ & $35^{\circ} \mathrm{C}$ & $40^{\circ} \mathrm{C}$ & $45^{\circ} \mathrm{C}$ & $50^{\circ} \mathrm{C}$ & $\mathbf{5 5}^{\circ} \mathrm{C}$ & $60^{\circ} \mathrm{C}$ \\
\hline 1 & 0.0000 & $0 \%$ & -45.23 & -44.87 & -44.47 & -44.07 & -43.63 & -43.27 & -42.87 & -42.57 & -42.03 & -41.80 & -41.40 \\
\hline 2 & 0.0718 & $10 \%$ & -43.30 & -42.90 & -42.60 & -42.20 & -42.10 & -41.87 & -41.57 & -41.30 & -41.07 & -40.60 & -40.30 \\
\hline 3 & 0.1483 & $20 \%$ & -41.90 & -41.60 & -41.33 & -41.07 & -40.70 & -40.40 & -40.13 & -39.83 & -39.53 & -39.20 & -38.90 \\
\hline 4 & 0.2299 & $30 \%$ & -40.83 & -40.50 & -40.23 & -39.90 & -39.63 & -39.30 & -39.03 & -38.73 & -38.30 & -38.10 & -37.83 \\
\hline
\end{tabular}


Passive Fiber Optic Evanescent Wave Sensor for the Measurement of Refractive Index at Various Temperatures Using a Tunable Light Source

\begin{tabular}{|c|c|c|c|c|c|c|c|c|c|c|c|c|c|}
\hline 5 & 0.3171 & $40 \%$ & -39.50 & -39.20 & -38.90 & -38.60 & -38.27 & -38.03 & -37.77 & -37.43 & -37.13 & -36.80 & -36.57 \\
\hline 6 & 0.4106 & $50 \%$ & -38.27 & -38.03 & -37.77 & -37.43 & -37.13 & -36.80 & -36.57 & -36.20 & -35.93 & -35.60 & -35.37 \\
\hline 7 & 0.5110 & $60 \%$ & -37.00 & -36.70 & -36.43 & -36.13 & -35.83 & -35.53 & -35.30 & -34.93 & -34.63 & -34.33 & -34.03 \\
\hline 8 & 0.6191 & $70 \%$ & -35.37 & -35.00 & -34.70 & -34.40 & -34.10 & -33.73 & -33.50 & -33.23 & -32.93 & -32.63 & -32.30 \\
\hline 9 & 0.7359 & $80 \%$ & -33.80 & -33.50 & -33.23 & -32.93 & -32.63 & -32.30 & -32.03 & -31.73 & -31.40 & -31.10 & -30.80 \\
\hline 10 & 0.8624 & $90 \%$ & -32.10 & -31.83 & -31.50 & -31.20 & -30.87 & -30.57 & -30.30 & -30.10 & -29.90 & -29.67 & -29.43 \\
\hline 11 & 1.0000 & $100 \%$ & -30.80 & -30.57 & -30.23 & -30.00 & -29.83 & -29.57 & -29.30 & -29.00 & -28.73 & -28.40 & -28.10 \\
\hline
\end{tabular}

The above procedure is followed by tuning the light source to the operating wavelengths of $820 \mathrm{~nm}$ and $850 \mathrm{~nm}$ separately and results are tabulated [table 3-4].

Table.3: Mole fraction and concentration of Acetone in Toluene + Acetone chemical mixture and Output power at various temperatures for the operating wavelength of the source $820 \mathrm{~nm}$.

\begin{tabular}{|c|c|c|c|c|c|c|c|c|c|c|c|c|c|}
\hline \multirow{2}{*}{$\begin{array}{c}\text { S. } \\
\text { No. }\end{array}$} & \multirow{2}{*}{$\begin{array}{c}\text { Mole } \\
\text { fraction } \\
\text { of } \\
\text { Acetone } \\
\end{array}$} & \multirow{2}{*}{$\begin{array}{l}\text { Concentration } \\
\text { of Acetone }\end{array}$} & \multicolumn{11}{|c|}{ Output Power(dBm) at various temperatures } \\
\hline & & & $10^{\circ} \mathrm{C}$ & $15^{\circ} \mathrm{C}$ & $20^{\circ} \mathrm{C}$ & $25^{\circ} \mathrm{C}$ & $3^{\circ} \mathrm{C}$ & $3^{\circ} \mathrm{C}$ & $40^{\circ} \mathrm{C}$ & $45^{\circ} \mathrm{C}$ & $\mathbf{5 0}^{\circ} \mathrm{C}$ & $5^{\circ} \mathrm{C}$ & $60^{\circ} \mathrm{C}$ \\
\hline 1 & 0.0000 & $0 \%$ & -46.87 & -46.47 & -46.17 & -45.73 & -45.30 & -44.93 & -44.57 & -44.27 & -43.77 & -43.43 & -43.07 \\
\hline 2 & 0.0718 & $10 \%$ & -45.00 & -44.60 & -44.47 & -43.93 & -43.80 & -43.50 & -43.27 & -43.00 & -42.77 & -42.30 & -42.00 \\
\hline 3 & 0.1483 & $20 \%$ & -43.57 & -43.30 & -43.00 & -42.77 & -42.40 & -42.10 & -41.77 & -41.50 & -41.23 & -40.90 & -40.73 \\
\hline 4 & 0.2299 & $30 \%$ & -42.47 & -42.20 & -41.93 & -41.57 & -41.30 & -41.00 & -40.73 & -40.43 & -40.03 & -39.80 & -39.50 \\
\hline 5 & 0.3171 & $40 \%$ & -41.20 & -40.90 & -40.73 & -40.30 & -40.00 & -39.70 & -39.43 & -39.13 & -38.87 & -38.50 & -38.27 \\
\hline 6 & 0.4106 & $50 \%$ & -40.00 & -39.70 & -39.43 & -39.13 & -38.87 & -38.50 & -38.27 & -37.83 & -37.60 & -37.30 & -37.03 \\
\hline 7 & 0.5110 & $60 \%$ & -38.70 & -38.40 & -38.13 & -37.80 & -37.50 & -37.23 & -37.00 & -36.57 & -36.33 & -36.00 & -35.70 \\
\hline 8 & 0.6191 & $70 \%$ & -37.03 & -36.70 & -36.40 & -36.10 & -35.80 & -35.40 & -35.17 & -34.90 & -34.60 & -34.33 & -34.00 \\
\hline 9 & 0.7359 & $80 \%$ & -35.50 & -35.17 & -34.90 & -34.60 & -34.33 & -34.00 & -33.70 & -33.40 & -33.10 & -32.80 & -32.50 \\
\hline 10 & 0.8624 & $90 \%$ & -33.83 & -33.50 & -33.17 & -32.93 & -32.53 & -32.23 & -32.00 & -31.70 & -31.47 & -31.20 & -30.97 \\
\hline 11 & 1.0000 & $100 \%$ & -32.50 & -32.23 & -31.93 & -31.57 & -31.40 & -31.13 & -30.87 & -30.53 & -30.33 & -29.97 & -29.70 \\
\hline
\end{tabular}

Table.4: Mole fraction and concentration of Acetone in Toluene + Acetone chemical mixture and Output power at various temperatures for the operating wavelength of the source $850 \mathrm{~nm}$.

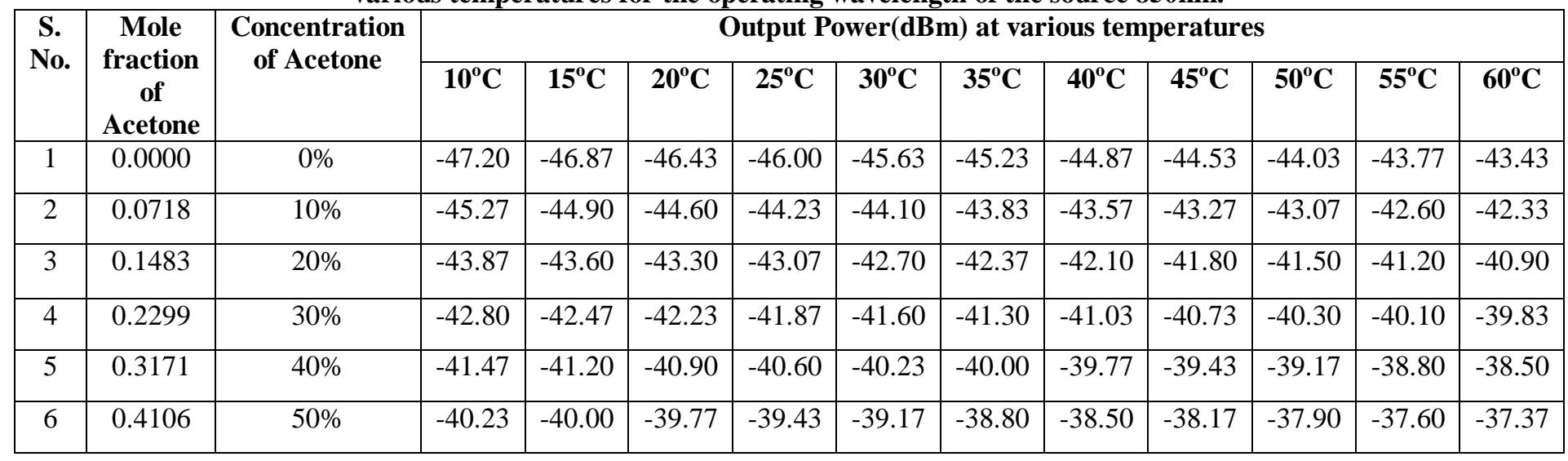


International Journal of Engineering and Advanced Technology (IJEAT) ISSN: 2249 - 8958, Volume-8, Issue-6S August 2019

\begin{tabular}{|c|c|c|c|c|c|c|c|c|c|c|c|c|c|}
\hline 7 & 0.5110 & $60 \%$ & -39.00 & -38.70 & -38.43 & -38.13 & -37.83 & -37.53 & -37.30 & -36.93 & -36.63 & -36.30 & -36.00 \\
\hline 8 & 0.6191 & $70 \%$ & -37.37 & -37.00 & -36.70 & -36.40 & -36.10 & -35.70 & -35.50 & -35.30 & -34.90 & -34.53 & -34.30 \\
\hline 9 & 0.7359 & $80 \%$ & -35.77 & -35.50 & -35.30 & -34.90 & -34.53 & -34.30 & -34.03 & -33.70 & -33.40 & -33.10 & -32.80 \\
\hline 10 & 0.8624 & $90 \%$ & -34.10 & -33.80 & -33.50 & -33.23 & -32.87 & -32.53 & -32.30 & -32.00 & -31.77 & -31.50 & -31.30 \\
\hline 11 & 1.0000 & $100 \%$ & -32.80 & -32.53 & -32.23 & -31.87 & -31.73 & -31.43 & -31.17 & -30.90 & -30.60 & -30.27 & -30.03 \\
\hline
\end{tabular}

By using an Automatic Digital Refractometer of modal $10^{\circ} \mathrm{C}$ to $60^{\circ} \mathrm{C}$ in steps of $5^{\circ} \mathrm{C}$ and experimental results are number RX-7000i (Atago make), the refractive index of tabulated [table-5]. each mixture was determined at temperature ranging from

Table.5: Mole fraction and concentration of Acetone in Toluene + Acetone chemical mixture and Refractive indices of mixtures at various temperatures.

\begin{tabular}{|c|c|c|c|c|c|c|c|c|c|c|c|c|c|}
\hline \multirow{2}{*}{$\begin{array}{c}\text { S. } \\
\text { No. }\end{array}$} & \multirow{2}{*}{$\begin{array}{c}\text { Mole } \\
\text { fraction } \\
\text { of } \\
\text { Acetone }\end{array}$} & \multirow{2}{*}{$\begin{array}{c}\text { Concentration } \\
\text { of } \\
\text { Acetone }\end{array}$} & \multicolumn{11}{|c|}{ Refractive Index at various temperatures } \\
\hline & & & $10^{\circ} \mathrm{C}$ & $15^{\circ} \mathrm{C}$ & $20^{\circ} \mathrm{C}$ & $25^{\circ} \mathrm{C}$ & $30^{\circ} \mathrm{C}$ & $35^{\circ} \mathrm{C}$ & $40^{\circ} \mathrm{C}$ & $45^{\circ} \mathrm{C}$ & $50^{\circ} \mathrm{C}$ & $55^{\circ} \mathrm{C}$ & $60^{\circ} \mathrm{C}$ \\
\hline 1 & 0.0000 & $0 \%$ & 1.50915 & 1.50591 & 1.50171 & 1.49770 & 1.49325 & 1.48974 & 1.48582 & 1.48293 & 1.47795 & 1.47509 & 1.47102 \\
\hline 2 & 0.0718 & $10 \%$ & 1.48997 & 1.48614 & 1.48305 & 1.48005 & 1.47922 & 1.47588 & 1.47298 & 1.47002 & 1.46720 & 1.46398 & 1.46004 \\
\hline 3 & 0.1483 & $20 \%$ & 1.47612 & 1.47308 & 1.47041 & 1.46720 & 1.46402 & 1.46112 & 1.45831 & 1.45523 & 1.45241 & 1.44905 & 1.44600 \\
\hline 4 & 0.2299 & $30 \%$ & 1.46528 & 1.46211 & 1.45923 & 1.45602 & 1.45323 & 1.45008 & 1.44734 & 1.44441 & 1.44128 & 1.43808 & 1.43548 \\
\hline 5 & 0.3171 & $40 \%$ & 1.45201 & 1.44905 & 1.44600 & 1.44307 & 1.44009 & 1.43714 & 1.43422 & 1.43119 & 1.42818 & 1.42504 & 1.42221 \\
\hline 6 & 0.4106 & $50 \%$ & 1.44009 & 1.43714 & 1.43422 & 1.43119 & 1.42818 & 1.42504 & 1.42221 & 1.41912 & 1.41600 & 1.41305 & 1.41008 \\
\hline 7 & 0.5110 & $60 \%$ & 1.42712 & 1.42428 & 1.42118 & 1.41821 & 1.41529 & 1.41221 & 1.40930 & 1.40618 & 1.40311 & 1.40054 & 1.39752 \\
\hline 8 & 0.6191 & $70 \%$ & 1.41008 & 1.40709 & 1.40411 & 1.40108 & 1.39814 & 1.39464 & 1.39218 & 1.39001 & 1.38627 & 1.38326 & 1.38018 \\
\hline 9 & 0.7359 & $80 \%$ & 1.39522 & 1.39218 & 1.39001 & 1.38627 & 1.38326 & 1.38018 & 1.37731 & 1.37424 & 1.37131 & 1.36854 & 1.36541 \\
\hline 10 & 0.8624 & $90 \%$ & 1.37824 & 1.37519 & 1.37224 & 1.36935 & 1.36605 & 1.36279 & 1.36011 & 1.35719 & 1.35424 & 1.35115 & 1.34827 \\
\hline 11 & 1.0000 & $100 \%$ & 1.36541 & 1.36279 & 1.35937 & 1.35635 & 1.35348 & 1.35010 & 1.34718 & 1.34425 & 1.34154 & 1.33829 & 1.33533 \\
\hline
\end{tabular}

\section{RESULT AND DISCUSSION}

The temperature study of refractive index of liquids paves the way for the understanding of macroscopic behavior of the liquids at various temperatures. The variation of refractive index and hence the concentration shows a direct relationship with the power reaching the detector at the room temperature.
As the refractive index of mixture increases, the output power decreases, which is an inverse power relationship with the concentration of the chemical mixture. The similar behavior is observed at each temperature of liquid taken in the steps of $5 \mathrm{oC}$ for each of chemical mixture from $10 \mathrm{oC}$ to $60 \mathrm{oC}$ when the source is fixed at the operating wavelength of $630 \mathrm{~nm}$ and results are shown in figures [fig.3-5]. 
Passive Fiber Optic Evanescent Wave Sensor for the Measurement of Refractive Index at Various Temperatures Using a Tunable Light Source

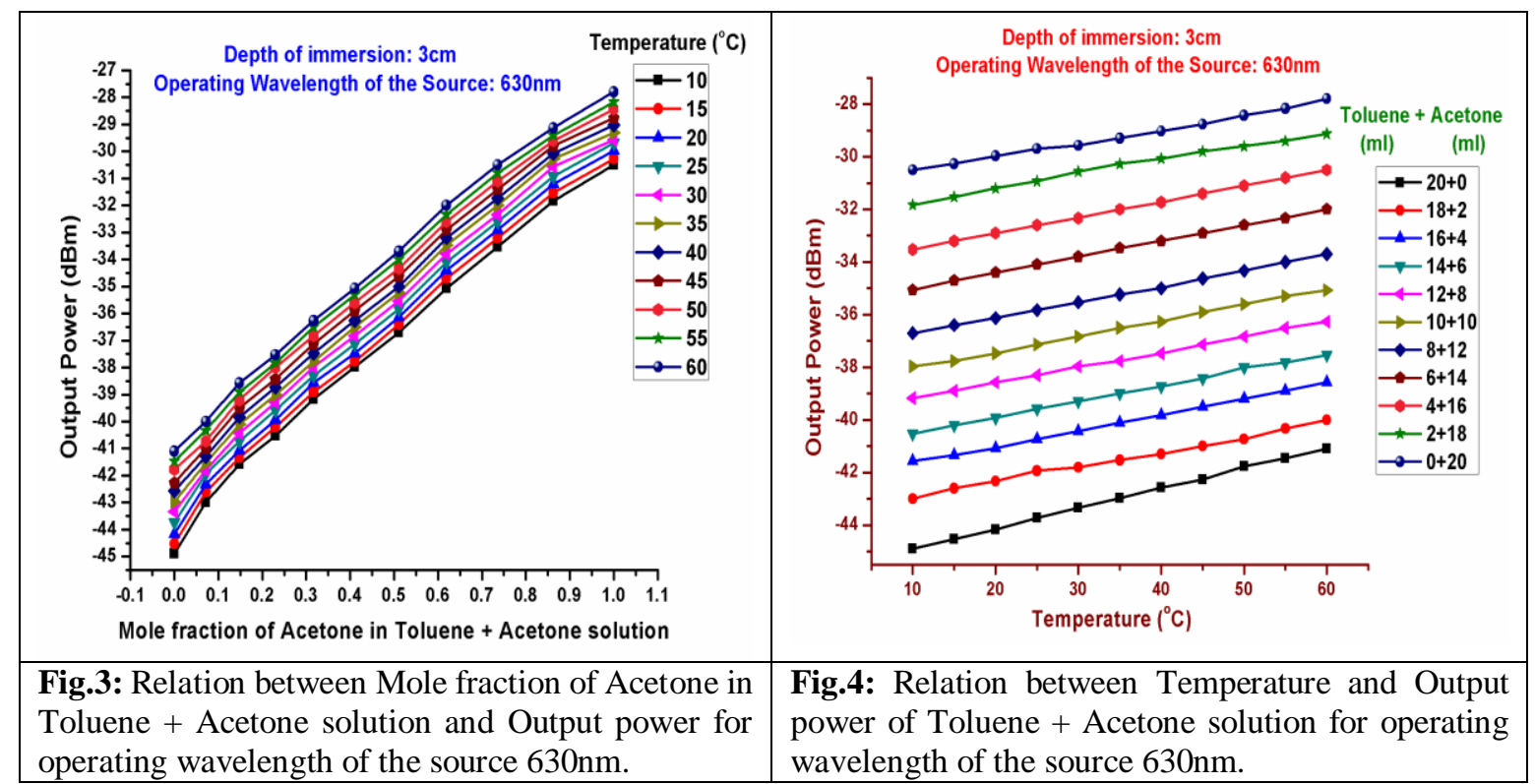

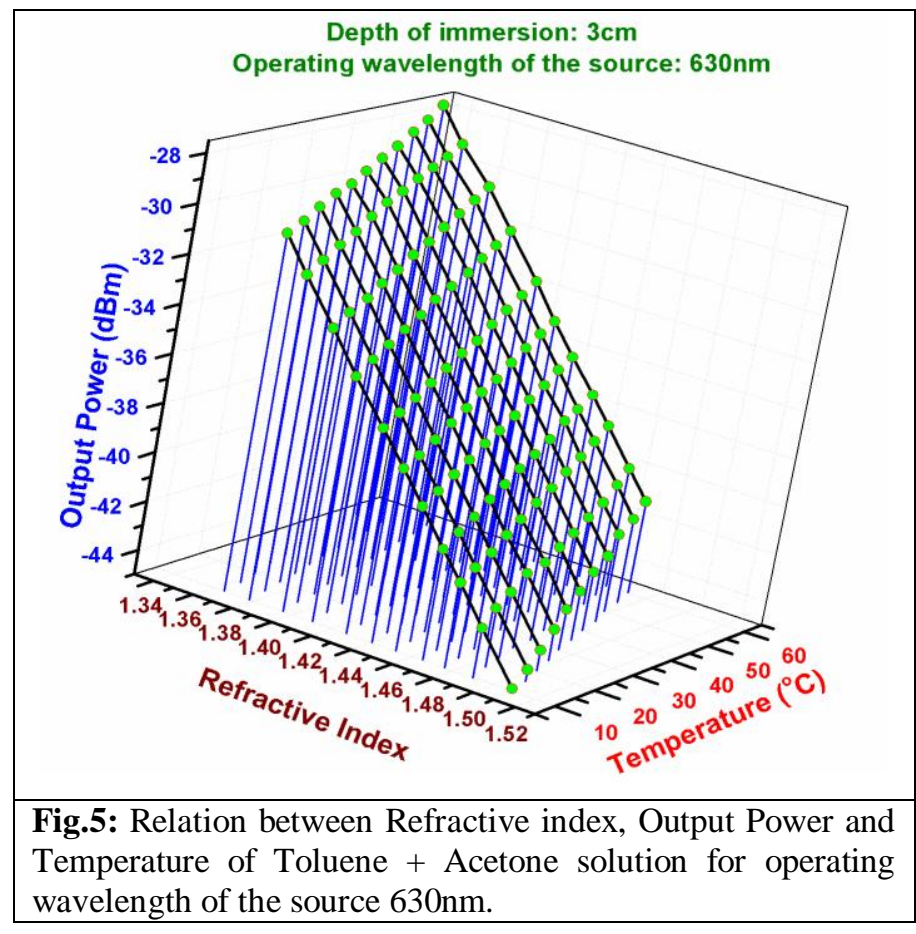

The experiment is performed with the source operating wavelength at $660 \mathrm{~nm}$ and the results are depicted graphically [fig.6-8]. 


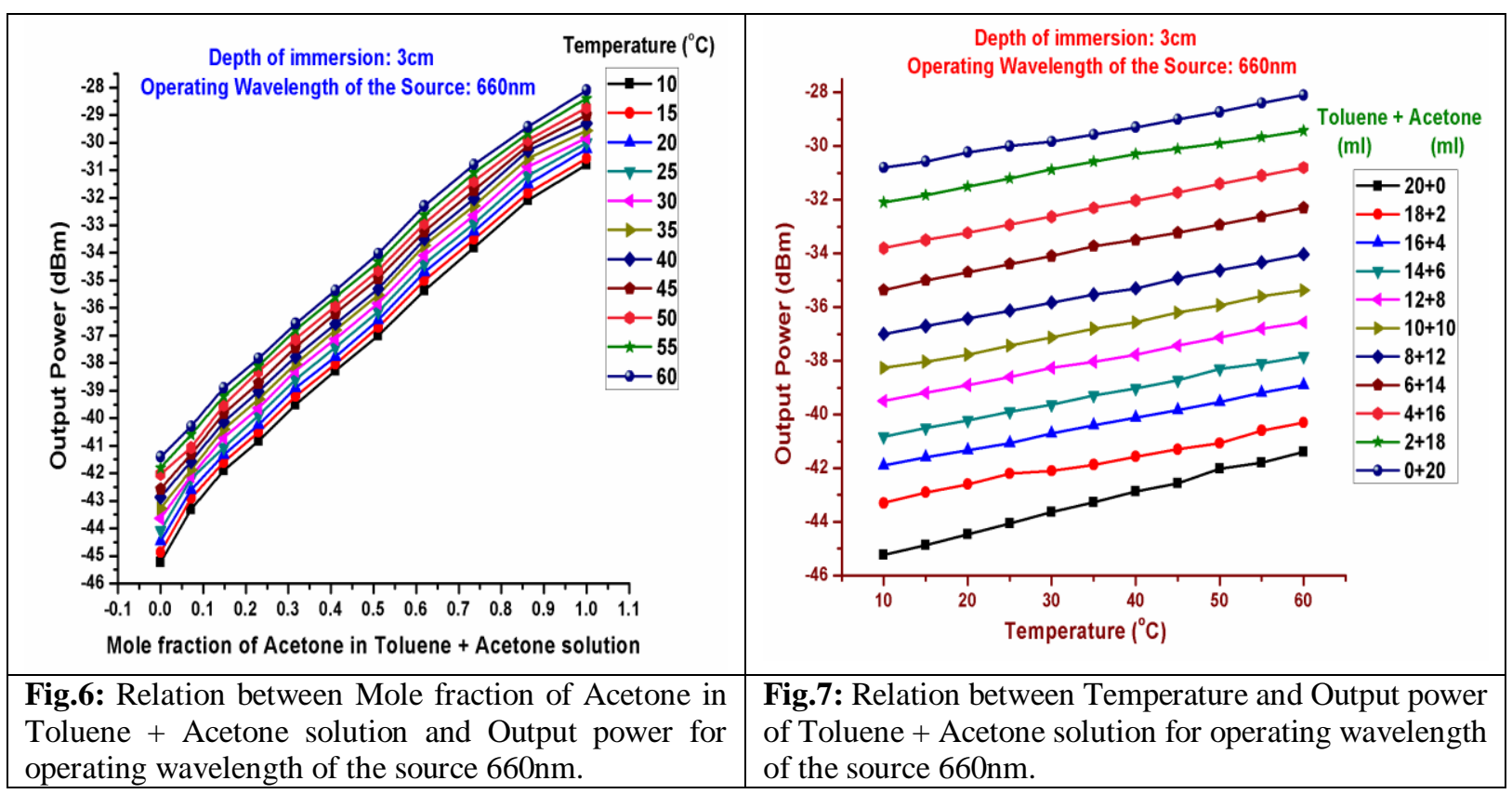

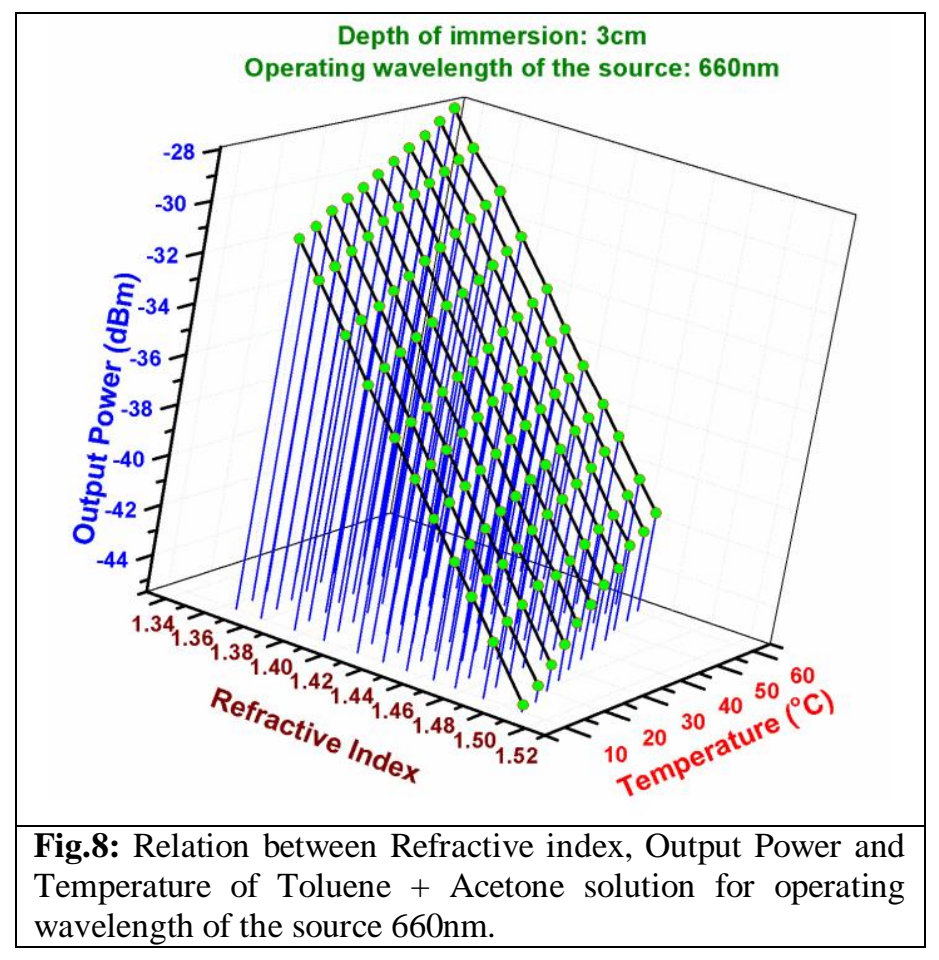

The variation in output powers at different temperature for various chemical mixtures shows that the output powers are reduces at the wavelength of $660 \mathrm{~nm}$ comparing with the $630 \mathrm{~nm}$. To ascertain the variation of output power with respect to wavelength two other wavelength $(820 \mathrm{~nm}, 850 \mathrm{~nm})$ also been considered and used in experimentation and results are obtained and the relationships between them are shown graphically [fig. 9-14]. 
Passive Fiber Optic Evanescent Wave Sensor for the Measurement of Refractive Index at Various Temperatures Using a Tunable Light Source

\begin{tabular}{|c|c|}
\hline 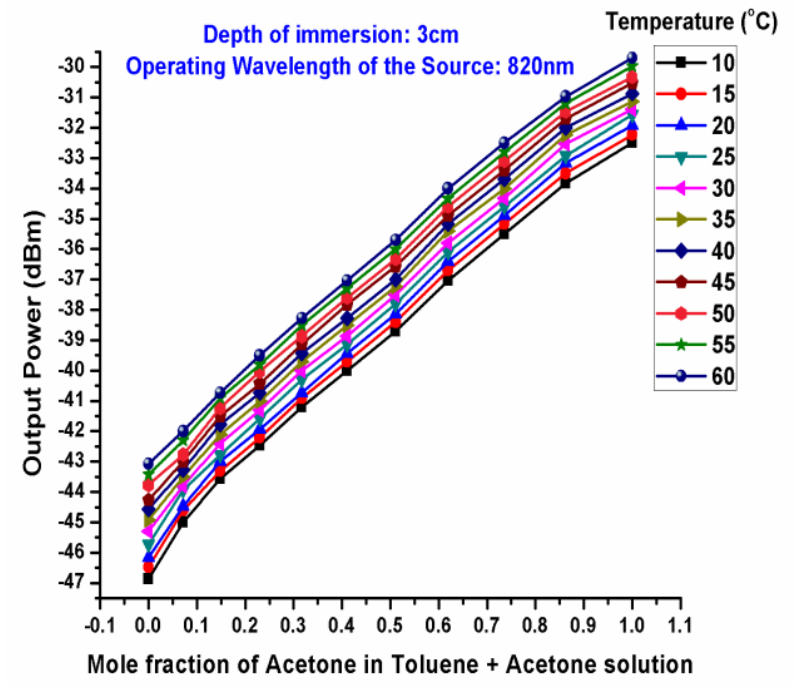 & Depth of immersion: $3 \mathrm{~cm}$ \\
\hline $\begin{array}{l}\text { Fig.9: Relation between Mole fraction of Acetone in } \\
\text { Toluene }+ \text { Acetone solution and Output power for } \\
\text { operating wavelength of the source } 820 \mathrm{~nm} \text {. }\end{array}$ & $\begin{array}{l}\text { Fig.10: Relation between Temperature and Output } \\
\text { power of Toluene }+ \text { Acetone solution for operating } \\
\text { wavelength of the source } 820 \mathrm{~nm} \text {. }\end{array}$ \\
\hline
\end{tabular}

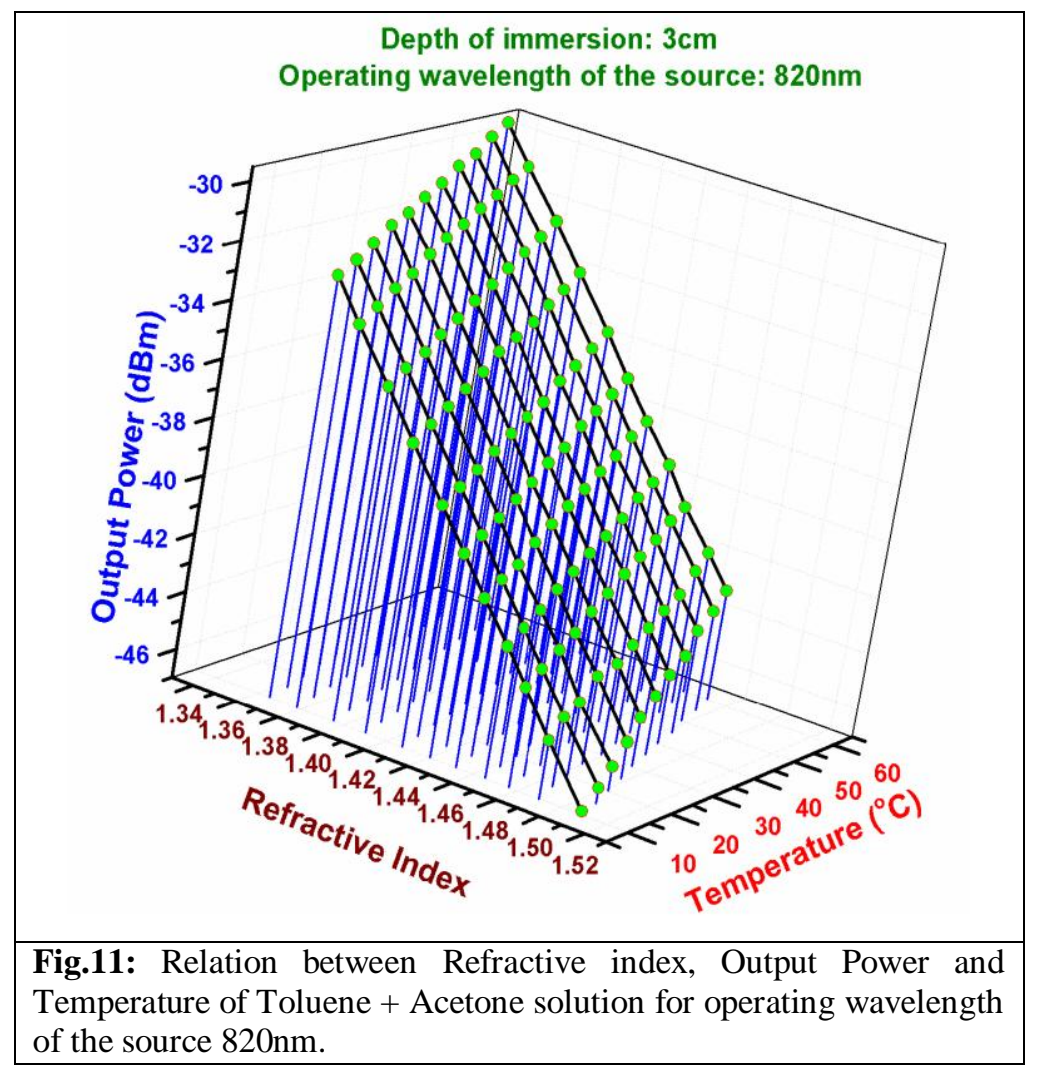




Depth of immersion: $3 \mathrm{~cm}$
Operating Wavelength of the Source: $850 \mathrm{~nm}$
Fig.12: Relation between Mole fraction of Acetone in
Toluene + Acetone solution and Output power for
operating wavelength of the source 850nm.

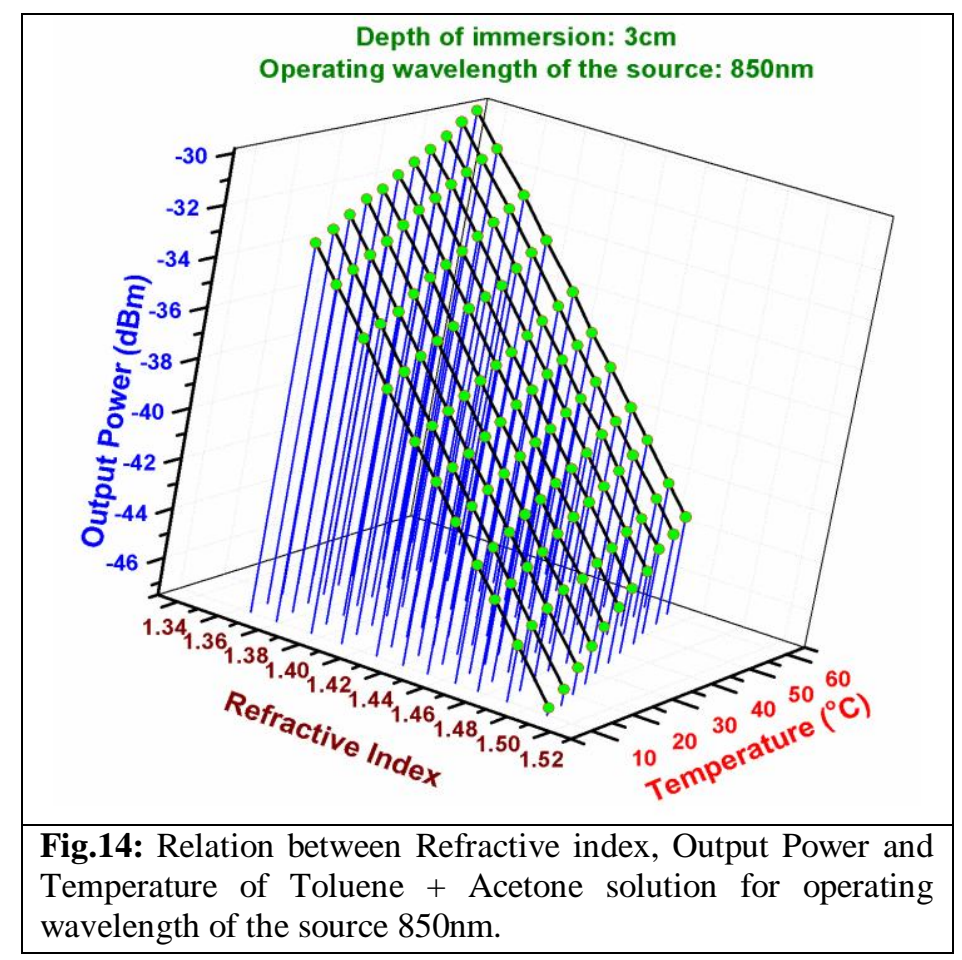

From the above graphs (figs. 9-14) it is confirmed that the output powers are reduced when the wavelength is increased. In addition to the study of power transmission in the sensor at different temperatures and at different operating wavelengths, the mole fractions and the concentrations of all the mixture at different temperature have been experimentally studied and the results are represented graphically [fig.15-17]. 

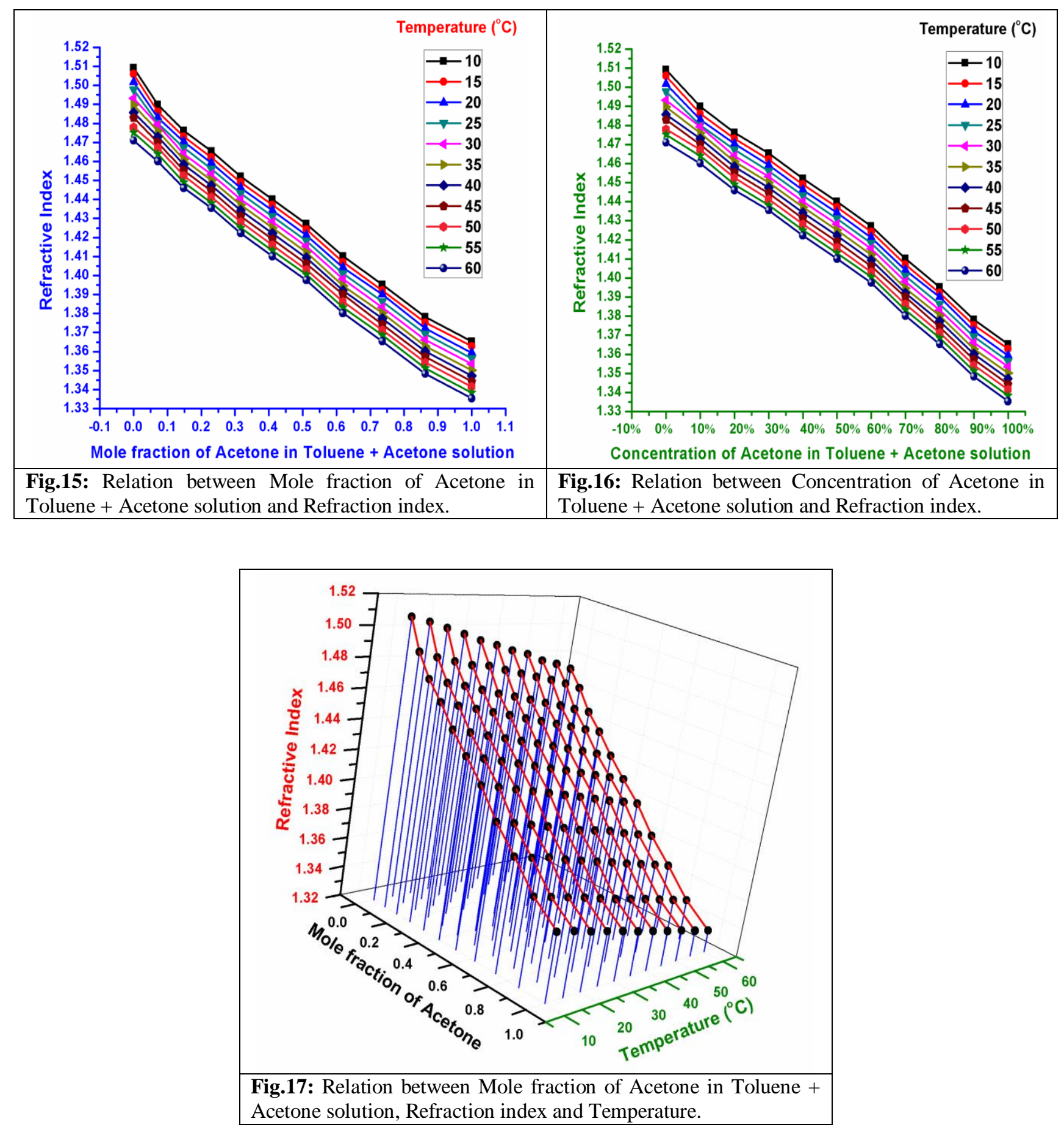

\section{CONCLUSION}

The study of operational nature of the passive fiber optic evanescent wave sensor for the measurement of refractive index at various temperatures using a tunable light source operating at the wavelengths of $630 \mathrm{~nm}, 660 \mathrm{~nm}, 820 \mathrm{~nm}$ and $850 \mathrm{~nm}$ has been taken up between temperature ranges from $10^{\circ} \mathrm{C}$ to $60^{\circ} \mathrm{C}$. The experimental results revels that the output power decreases with increasing the refractive index hence concentration of chemical mixture forms as a liquid cladding at any fixed value of temperature. The output power also decreases when the operating wavelength of the tunable light source increase which is also in agreement with the literature values. The decrease of refractive index of chemical mixture at high temperatures has nominal affect above room temperature i.e., from $30^{\circ} \mathrm{C}$ to $60^{\circ} \mathrm{C}$ and also the increase in refractive index of chemical mixture at low temperature also has a little affect when temperature reduces from $30^{\circ} \mathrm{C}$ to $10^{\circ} \mathrm{C}$ below room temperature.

\section{REFERENCES}

1. Vollmer, F., Arnold, S., "Whispering- gallery - mode bio-sensing: label-free election down to single molecules.

2. Taitt, C. R., Anderson, G. P., Ligler, F. S., "Evanescent wave fluorescence biosensors", Biosensors and Bioelectronics, Vol. 20, Issue 12,2005 , pp. 2470-2487.

3. Taitt, C. R., Anderson, G. P., Ligler, F. S., "Evanescent wave fluorescence biosensors: Advances of the last decade", Biosensors and Bioelectronics, Vol. 76, 2016, pp. 103-112.

4. Eggleton, B. J., Luther-Davies, B., Richardson, K., "Chalcogenide photonics", Nature Photonics, 5, 2011, pp. 141-148. 
5. Dr. S. Venkateswara Rao, S. Srinivasulu, "Analysis of Sensitivity of an Extrinsic Fiber Optic Sensor Based on U-Shaped Glass rods with Different Geometries Employed as Sensing elements using Binary Liquids at $660 \mathrm{~nm}$ Wavelength", International Journal of Management, IT \& Engineering, Vol. No.7, Issue No.1, pp.330-336, Jan-2017.

6. Homola, J., Yee, S. S., Gauglitz, G., "Surface plasmon resonance sensor: review", Sensors and Actuators B: Chemical, Vol. 54, Issues 1-2, 1999, pp.3-15.

7. Fagerstam, L. G., Frostell-Karlsson, A., Karlsson, R., Persson, B., Ronnberg, I., " Biospecific interaction analysis using surface Plasmon resonance detection applied to kinetic, binding site and concentration analysis", Journal of Chromatography A, Vol. 597, Issues 1-2, 1992 , pp.397-410.

8. Bhatia V, Cambell D K, Sherr D, D' Alberto T G, Zabaronick N A, Ten Eyck G A, Murphy K A and Claus R O, 1997, Opt. Eng. 36, 1872.

9. Khaliq S, James S W and Tatam R P, 2001, Opt. Lett., 26, 1224.

10. Patrick H J, Kersey A D and Buchotlz F, 1998, J. Lightwave Technol., 16, 1606.

11. Patrick H J, 2000 Electron, Lett. 26, 1763.

12. Ye C C, James S W and Tatam R P 2000, Opt. Lett, 25, 1007.

13. Liu Y, Zhang L, Williams J A R and Bennion I, 2000, IEEE Photon, Technol., Lett., 12, 531.

14. S. Srinivasulu, Dr. S. Venkateswara Rao, "Influence of Geometrical Parameters on the Transmission Characteristics of a U-Shaped Glass Probe: Determination of the Sensitivity of an Extrinsic Fiber Optic Refractometer", Journal of Emerging Technologies and Innovative Research, Vol. No.5, Issue No.9, pp.341-346, Sep-2018.

15. Bhatia V, 1990 Opt. Exp., 4, 457.

16. Messian, A. Greenstein and A. Katzir, "Theroy of fiber optic evanescent wave spectroscopy and sensors, 1996, Applied optics, Vol. 35, No. 13.

17. U. Willer, D. Scheel, I. Kostjucentko, "Fiber optic evanescent field laser sensor for in-situ gas diagnostics spectrochim”, Acta, 2002 Part-A 58, pp. 2422-2427.

18. W. Love, L. Button, R. Slovacek, "Optical characteristics of fiber optic evanescent wave sensors", 1991, In: Wise, Wingard (Eds.), Bi-sensors with fiber optics, Humana press, Totowa, NJ, p.139.

19. G. Z. Wang, K. A. Murphy, R. O. Claus, "Effect of external index of refraction on multimode fiber coupler", 1995, Applied Optics, 34(36), pp.8289-8293

\section{AUTHOR PROFILE}

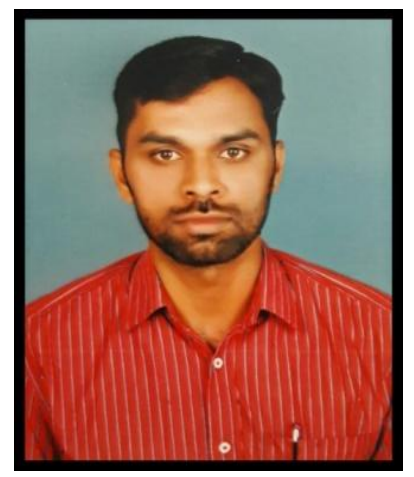

S.SRINIVASULU [M.Sc.(Physics), M.Sc.(Maths), B.Ed., BLISc., CSIR-NET, LMISCA], Ph.D. Research Scholar, UGC-Senior Research Fellow (SRF), Department of Physics, College of Engineering Hyderabad, Jawaharlal Nehru Technological University Hyderabad, Telangana State, India. He has published 20 research papers in reputed International Journals and presented 10 research papers in International Conferences. 